\title{
As Crippled As It Gets: Dalton Trumbo's Johnny Got His Gun (1939; 1971)
}

\begin{abstract}
Dalton Trumbo's novel Johnny Got His Gun (1939) has come to be known as one of the strongest pacifist statements in American literature. In 1971 Trumbo returned to the topic with an eponymous film based on his own novel. By that time, however, both the personal situation of the author and the mood in the country had changed, and the nation was divided over the issue of the war in Vietnam. The paper seeks to offer a contrastive analysis of the novel and the film and situate them in their respective personal and social contexts. It examines the manner in which the young Trumbo is interpreted by the older Trumbo and it comments on the reception of both works.
\end{abstract}

Key words

Dalton Trumbo; Dalton Trumbo's Johnny Got His Gun (1939); film adaptation (1971); book and film reception

Johnny held a different meaning for three different wars. (Trumbo 1939: 2)

Somewhere in a military hospital a mind awakens. It belongs to Joe Bonham, American soldier, profoundly mutilated by a WWI shell. Joe is a quadriplegic amputee, thus unable to move, a mere stump of a body on a hospital bed hidden away to prevent unease among the other wounded and personnel. To make matters worse, even his jaws and face have been blown away, depriving their unhappy bearer of the senses of hearing, sight and smell. The tactile sense remains the only one left. Yet locked within this helpless torso there is an intellect capable of reflection, which has feelings and memories, trying to break through and communicate with the outside world.

Based on the true story of a WWI soldier, Dalton Trumbo's novel Johnny Got His Gun came to be known as one of the strongest pacifist statements in Ameri- 
can literature of the twentieth century. Yet the novel was not only pervaded by an intense anti-war sentiment; echoing the idealism of the New Deal Generation, Trumbo also spoke passionately about the attraction of family life and common, working-class experience in the United States. The fact that the narrative of the deeply disfigured and at times hallucinating hero is full of autobiographical detail is indicative of a distinct personal involvement on the part of the author.

More than thirty years later, in 1971, Trumbo returned to the topic, writing and directing the eponymous film based on his own novel. By that time, however, both the personal and social contexts had changed. Trumbo was sixty-five years old, a survivor of more than a decade of Hollywood blacklisting, and the nation was divided (and traumatized) over the issue of the war in Vietnam. This paper seeks to offer a contrastive analysis of both the novel and the film and situate them in their respective personal, social and cultural contexts. It will examine the manner in which the young Trumbo is interpreted by the older Trumbo and it will also briefly comment on the reception of both works.

In regard to the question of adaptations, my theoretical vantage point is, rather obviously, informed by a fundamental skepticism towards what Robert Stam calls fidelity discourse in adaptation studies. Clearly, as there is no particular "semantic core, a nucleus of meaning ascribable to novels, which adaptations are presumed to 'capture' or 'betray" (2005: 10) the search for such a core is both futile and uninteresting. Rather, a much more worthwhile project for adaptation studies is to investigate the process of "reaccentuation, whereby a source work is reinterpreted through new grids and discourses. Each grid, in uncovering aspects of the source text in question, also reveals something about the ambient discourses in the moment of reaccentuation" (Stam 2005: 45). By providing a contrastive look at the two works and their reception, then, I hope to offer several insights into a variety of issues: Trumbo in the late 1930s and early Forties; the altering attitudes of Trumbo and his reading public in changing historical circumstances; and Dalton Trumbo's motivation and political positions in the early Seventies, as they manifest themselves in his sole directorial endeavor.

\section{The Novel}

The novel's central theme is the damage inflicted by modernity - its standardized, mass-produced, heartless butchery in WWI - on a particular individual. Johnny's surviving disfigured body becomes a sign threatening to subvert the traditional rhetoric mobilizing the masses to fight for their king, democracy, humanity, etc. Therefore it has to be rendered invisible, kept apart from other patients and staff, save for those directly responsible for its care. It is precisely for this reason that Joe cannot be granted the fulfillment of his wish to go out into the world and pay for his upkeep by being displayed in a funfair sideshow as an educational (or curiosity) exhibit. If the hero has been deprived of the possibility to bring home to the people the message of the madness of modern warfare, the novel has not. 
It becomes one of the most eloquent literary statements of American pacifism.

Another central theme of the novel is human isolation. Being limbless and practically without senses, Joe's situation is certainly quite specific, depriving the unhappy hero of the most basic temporal and spatial coordinates normally situating a person in their reality. Under such circumstances it appears next to impossible not only to tell the place and time and to know the identity of people around oneself, but also to distinguish between what is imagined and what actually happens. Even at the moment of "breaking through" by means of Morse code tapping with his head, Joe remains thoroughly alone as his wishes fall on deaf ears.

To represent Joe's plight at its most authentic Trumbo selects the narrative perspective of a subjective personal narrator drifting in and out - at times in a kind of stream of consciousness fashion - of his ordinary reality, oscillating between actual events happening in and around his bed and his memories and fantasies. Reminiscences from Joe's boyhood and youth are for the most part autobiographical, based on Trumbo's experiences from his growing up in Grand Junction, Colorado, and later in Los Angeles. Here Trumbo meditates on the nature of failure and success as traditionally conceived in the United States, speaks fondly about his family and particularly his father and celebrates the various virtues of the common, working-class life. Although the existence of his family was not marked by material success, we are told, there was dignity, mutual care, friendship, sensual pleasure and a lot of love.

When denied his freedom, at the end of the novel, Joe has a vision "of himself as a new kind of Christ as a man who carries within himself all the seeds of a new order of things. He was the new messiah of the battlefields saying to people as I am so shall you be" (103). What follows is a description of apocalyptic scenes after the possible new war and then, all of a sudden, Joe's perspective disappears. Speaking on behalf of the common man, he says:

We are men of peace we are men who work and we want no quarrel. But if you destroy our peace if you take away our work if you try to range us one against the other we will know what to do. If you tell us to make the world safe for democracy we will take you seriously and by god and by Christ we will make it so. We will use the guns you force upon us we will use them to defend our very lives and the menace to our lives does not lie on the other side of a nomansland that was set apart without our consent it lies within our own boundaries here and now we have seen it and we know it.

Put the guns into our hands and we will use them...

...Give us the slogans and we will turn them into realities. Sing the battle hymns and we will take them up where you left off. Not one not ten not ten thousand not a million not ten millions not a hundred millions but a billion two billions of us all the people of the world we will have the slogans and we will have the hymns and we will have the guns and we will use them and we will live. Make no mistake of it we will live. We will be alive and we 
will walk and talk and eat and sing and laugh and feel and love and bear our children in tranquility in security in decency in peace. You plan the wars you masters of men plan the wars and point the way and we will point the gun.

(Trumbo 1939: 104)

The problem is that Joe no longer has any hands to point the gun with. Consider this: a novel whose author meticulously adheres to the selected narrative perspective, thus skillfully evoking the horror of individual helplessness and entrapment, suddenly morphs into a manifesto of determined collective action. The accusing finger caused by compassion becomes a threatening fist of forceful declaration, demanding not only peace but also, perhaps, revolution. For the purpose of delivering this manifesto, the unity of narrative perspective, so effectively communicating the plight of a wounded, isolated individual has to be sacrificed. Militant pacifism, glorifications of the common man - these ingredients are not unknown. The book reflects the positions of the American left in the interwar period very well.

The novel was finished at the beginning of 1939. At that moment Austria had already been annexed, the Munich agreement signed, the invasion of the remains of Czechoslovakia imminent, the attack on Poland - and the outbreak of World War II - a mere half a year away. Trumbo's biographer Bruce Cook claims that it was the author's intention to get his anti-war message across as quickly as possible (1977: 129). But things had moved far too much for a mere novel to stop them, no matter how strong its appeal. To speed matters up, Trumbo even changed the publisher. Yet despite the short time that elapsed between the signing of contract with J.B. Lippincott and the book's appearance, Johnny was published on September third, two days after the German attack on Poland (Trumbo 1939: 1). The first reviews started to appear when "World War II was several days underway". "All of them were respectful..." (Cook 1977: 130-131).

The novel's publication almost coincided with the signing of the MolotovRibbentrop Pact. Trumbo as a Communist sympathizer and future card-carrying member was frequently accused of mere supplying propaganda ammunition for the sudden turn in foreign policy of Stalin's Soviet Union (and its endorsement of pacifism and declaration of neutrality in relation to Nazi Germany). Yet Cook claims this is mere coincidence. Writing on his newly purchased California ranch during the year of 1938, Trumbo could not have foreseen this unexpected turn in international affairs.

Johnny won the American Booksellers Award (the precursor to the National Book Award) in 1939. In a speech made in February 1940, Trumbo said: "If they say to us, 'We must fight this war to preserve democracy,' let us say to them, 'There is no such thing as democracy in time of war. It is a lie, a deliberate deception to lead us to our own destruction. We will not die in order that our children may inherit a permanent military dictatorship" (qtd. in Hopwood).

Later, however, Trumbo's principled pacifist position changed. Writing in 1959 he describes his radically altered position in regard to the message of his book 
and its possible uses during the wartime days. He even goes as far as to make a striking confession:

As the conflict deepened, and Johnny went out of print altogether, its unavailability became a civil liberties issue with the extreme American right. Peace organizations and "Mothers" groups from all over the country showered me with fiercely sympathetic letters denouncing Jews, Communists, New Dealers and international bankers, who had suppressed my novel to intimidate millions of true Americans who demanded an immediate negotiated peace.

Nothing could have convinced me so quickly that Johnny was exactly the sort of book that shouldn't be reprinted until the war was at an end. The publishers agreed. At the insistence of friends who felt my correspondents' efforts could adversely affect the war effort, I foolishly reported their activities to the F.B.I. $(1939,1959: 2)$

It is a major paradox that the author of this eloquent pacifist plea becomes essentially complicit in an attempt to limit the book's circulation; he even goes as far as to inform the authorities on the people who still embrace and appreciate his previously held principles and act accordingly. Such a dramatic turn can hardly be explained unless one takes into account the fact that since Operation Barbarossa and Pearl Harbor the Communist Soviet Union was an American ally. Given Trumbo's sympathies and future party membership, the suppression of Johnny must have been a necessary sacrifice. (And reporting was a wide-spread practice among the comrades from the very beginning.)

What followed was a familiar history for those acquainted with the history of the Hollywood blacklist. In 1943 Trumbo joined the Communist Party, in October 1947 was called to testify before the HUAC, "took the First Amendment claiming the committee had no right to inquire into his political beliefs, and was found in contempt of Congress, fined $\$ 10,000$, and sentenced to a year in prison" (N. Trumbo 2005: 98). Having served ten months, Trumbo and his family moved to Mexico in 1951, but returned to Los Angeles in 1954. Originally one of the best paid screenwriters in the business, Trumbo was forced to work on the black market, supplying a multitude of scripts at much lower prices, fronted by other people. He was honored with an Oscar for the screenplay of Roman Holiday (1953), which he was awarded posthumously in 1993, 16 years after his death. Under the name Robert Rich he won an Oscar in 1956 for The Brave One. In the same year he also quietly left the American Communist party. While probably one of the most flexible and skilled writers of his day (and the most successful of the famous Hollywood Ten), his most notable achievement was the breaking of the Hollywood blacklist with Exodus, directed by Otto Preminger, and Spartacus, directed by Stanley Kubrick and produced by Kirk Douglas (both films appeared in 1960). 


\section{The Film}

The 1971 adaptation of Johnny is Trumbo's sole directorial effort, one to which he also supplied the script. According to Peter G. Hanson "it is by far the most personal of Trumbo's film projects and also the most experimental" (2001: 185). One of the great masters of world cinema, Louis Buñuel, only had words of praise for Trumbo's adaptation. "I like Johnny Got His Gun enormously. For me the film has the same power as the novel. It has the same disturbing quality, and moment of extremely powerful emotion. The film left an impression on me that is among the strongest I have ever experienced" (qtd. in Nesbit). The fact that the novelist is adapting his own work for the screen, which he then even directs, is highly unusual and invites commentary on a variety of mutually interrelated issues: Trumbo in the late Thirties vs. Trumbo in the early Seventies; the possibilities of narrative expression of literature vs. cinema; and the reception of the film.

An obvious obstacle to tackle was that of perspective. Practically the whole narrative of the novel remains confined to the recording of Johnny's sensory impressions, memories and fantasies. How to translate an extreme subjective situation - verging on that of a brain in a vat - into the more objective medium of film? Unless one wants to alienate the viewer, standard cinema can't remain confined to the subjective point of view of the protagonist, not to mention a paralyzed one. Other characters and their actions concerning Johnny need to be invented and shown, actions that are obviously beyond the reach of the hero's extremely limited sensory input. For the hospital sequences Trumbo opted for a standard narrative form where Johnny's point of view is constantly supplied by the voiceover.

Another serious problem was the rendering of the drifting of Johnny's mind between the present and the past, reality and fantasy. This is achieved by the use of color and application of filters: the present, i.e. scenes taking place in the hospital are shot in black and white; Johnny's personal memories and fantasies are shot in color. The more dreamy and unreal the scene becomes, the more saturated are the colors and blurry the image. Such coding, with its traditional symbolism, allows for an easy orientation between the various temporal and epistemic levels of the narrative.

Trumbo presented some of the novel's most notable episodes, characters and visions: the death of Joe's beloved dad; his girlfriend Kareen and the figure of her working-class father, generously allowing the two young people to spend the night in the family bedroom prior to Joe's joining the army; the fishing trip when Joe and his friend Bill lose Joe's father's most valuable possession a very special fishing pole; and also the "dreamlike vision of Jesus riding the night train carrying the dead soldiers, ambiguously shouting in ecstasy or sorrow" (Nesbit). Due to budgetary limitations, the movie does not include major exterior sequences set in Grand Junction, alias Shale City, and surroundings, save for the important moment of the fishing trip. While its scope is circumscribed by the inner circle of immediate family, it still manages to communicate very well the range of experience available to an American Everyman growing up in a small town. 
In addition to one extra scene with a hip, hippie-like Jesus, apparently designed to grant more screen space to Donald Sutherland, Trumbo also introduces the theme of mercy killing. When denied his wish to go out into the world and be displayed, Joe starts tapping incessantly: "Kill me, kill me". A compassionate nurse attempts to make his wish come true and put an end to his misery but is prevented from doing so by a medical officer in charge. This leaves Joe totally powerless, begging for help before the final fade to black.

This ending thus represents a most conspicuous departure from the book. While the novel ends with a proclamation of determined action for the sake of peace, the film closes with an anguished cry for help by the hero forever trapped in his permanent dark loneliness. Perhaps the 65 -year-old author did finally realize that sympathy with the suffering of an individual victim can affect viewers more than open political rhetoric, that the fate of this paralyzed soldier offers more in the way of understanding war's ultimate monstrosity than pacifist manifestoes.

Naturally, Trumbo made sure that the message of the film did not get lost, anyhow. It is particularly Joe's father that serves as Trumbo's mouthpiece. The following exchange offers an apt illustration of its didactic irony.

'What is Democracy?' asks the ten-year-old Joe.

'I don't know, son. It's a kind of government that seems to have something to do with young men having to go out and kill each other.' [...]

'When it comes my turn, would you want me to go?'

'For Democracy any man would give his only begotten son.' (Trumbo 1971)

The outside perspective necessitated the development of some other characters, particularly in the hospital scenes. As they belong to the various professions responsible for Joe's care, they include nurses, army doctors and a chaplain. Except for the compassionate nurse who cries over his body, caresses Joe at one point, and breaks through to him by developing an ingenious system of communication, the others show little sympathy or emotional involvement. Here, Trumbo is making the point that medicine and religion are just as complicit in destroying an innocent individual as the military. According to him, there are basically no major differences between the various branches of the state apparatus as they heartlessly "process" the disfigured body, and subsequently suppress its subversive signification. The same message is communicated by the book:

The war had been a wonderful thing for the doctors and he was the lucky guy who had profited by everything they learned. But there was one thing they couldn't do. They might be perfectly able to put a guy back into the womb but they couldn't get him out again.

But there weren't many like him. There weren't many guys the doctors could point to and say here is the last word here is our triumph here is the greatest thing we ever did and we did plenty. Here is a man without legs or arms or ears or eyes or nose or mouth who breathes and eats and is just as 
alive as you or me. The war had been a wonderful thing for the doctors and he was the lucky guy who had profited by everything they learned.

Leaving aside the touching nostalgic reminiscences of Joe's small town youth, the text of the novel is at its most effective in passages such as this one. Such biting irony, however, did not find its way into the film. Its earnest message is either delivered with the solemnity of a sermon; its ironies now almost verging on parody (see the above exchange).

Given the historical circumstances, as in 1939, Trumbo again felt a great urgency to put Johnny on the screen. He hoped that its anti-war message could reach "a new and potentially more responsive generation. If it were ever to be produced, this was surely the time" (Cook 1977: 301). When the funds were low, Trumbo even contributed 25000 dollars from his own back account. Having invested a year and a half of his life and a substantial sum of money, Trumbo gambled high on the movie's success, but the small-budget, independently financed production was a commercial as well as critical failure. "The important reviews from the younger reviewers who might have saved the film all ran against it" (Cook 1977: 304). Roger Greenspun's review in the New York Times provides a good example:

"Johnny Got His Gun" has perhaps two ideas: one, that war is a crime, and two, that it is a crime committed by the old against the young. The first of these ideas seems unquestionable, but uninteresting. The second, though questionable, is also uninteresting. And yet they are virtually all the thought that gets into the film, the rest being a mess of clichéd, imprecise sentimentalizing and fantasizing. On any terms that I might recognize and possibly credit, "Johnny Got His Gun" is a stultifyingly bad movie.

Although Mr. Trumbo is primarily a screenwriter [...], screenwriting is only the worst of the film's several failures. [...]

The hospital scenes, in setting very drab and rather formal, in the style of 1930's serious-movie interiors, are the most acceptable - until they are ruined by Diane Varsi, a kindly nurse who finally gets through to Joe, in what may be one of the worst performances in the history of movies.

(Greenspun 1971)

Yet the global reception of the film was not as hostile. Whenever the American artist fails in finding appreciation at home, they might still hope to enlist the sympathies of the French. At the 1971 Cannes film festival Johnny received the Grand Prize of the Jury (along with another commercial failure: Miloš Forman's American debut Taking Off). It also received the FIPRESCI Prize. In a similar manner the European reviews have tended to hail Trumbo's film as a key work of the protest movement against the war in Vietnam and one of the most radical films in the history of cinema made since that time. 
Once again, one can see that beauty - or a film's quality - rests firmly in the eye of the beholder. Whereas the Americans appear to have viewed the film solely as an art form, and chose to downplay the topicality of the film's urgent political message, the European take seems to have done the obverse: it was precisely the pacifism of the film (perhaps along with the dream sequences reminiscent of the art cinema of some European auteurs) that probably made it so endearing to the European eye. It is also obvious that a critical stance toward the war in Vietnam would not yet have been taken by Hollywood in those days. Like Trumbo's independently produced Johnny, the other important war films of the day - most notably Mike Nichols' Catch-22 and Robert Altman's MASH - clearly enter the context of the U.S. anti-war protests with a strong anti-war, anti-authoritarian message while being duly set in other places and wars. Their audiences nevertheless knew...

A striking change in the American perspective can be noted in 1987 when the heavy metal band Metallica took the theme of Johnny as basis for the text of the song 'One' and used the most notable scenes from Trumbo's film for their very first clip. "It was released as the third and final single from their fourth album ...And Justice for All. 'One' was also the band's first Top 40 hit single, reaching number 35 on the Billboard Hot 100. It is one of the band's most popular songs and has remained a permanent live staple since the release of the album, making this the most played song from the album" (Wikipedia). The current number of the clip's Youtube views is over 38.5 million, with more than 111,000 likes, the numbers rising constantly. If Dalton Trumbo were alive today, he would be pleased.

\section{Conclusion}

WAR DEAD SINCE 1914: OVER 80,000,000, MISSING OR MUTILATED: OVER 150,000,000. "DULCE ET DECORUM EST PRO PATRIA MORI" (Trumbo 1971). These figures, juxtaposed against a noble patriotic slogan in Latin, flash on the screen before the final credits. They represent the gist of Trumbo's anguished cry: how little has changed between World War I and the war in Vietnam! After three generations, one is still going through the same experience with millions of young lives being wasted constantly!

The fact that the filmmaker opted for Latin as the language of the motto is at the same time indicative of some of the reasons why his message was not appreciated by multitudes of American cinema-goers. How many of his viewers would have sufficient command of the language to properly appreciate its bitter irony? The same goes for the language of the film itself. Can't the film's arthouse air be held responsible for its poor commercial performance? Was it not the unusually-staged and executed dream sequences - at times evocative of a Buñuel or a Fellini - that possibly alienated many? The major obstacle, however, was an adherence to formulas that might have been perceived not only as alien but 
as somewhat obsolete in the days of New Hollywood with its vigorous stylistic and thematic innovations. The success of Robert Altman's idiosyncratic anti-war, anti-establishment narrative of MASH, made just one year prior to Johnny, can be used as a good case in point. American audiences of the day were ready for anti-war films but they responded only to those that were marked by novelty and freshness of approach. The film version of Johnny, obviously, also battled against the limitations of commercial cinema. The subjective internal perspective, which works so well throughout most of the novel, has not found an adequate translation in the film's voice-overs, or in the added dramatic action.

Nevertheless, it would be unfair to entirely dismiss Trumbo's film effort. While he appears to have given up on his earlier revolutionary ardor, which found it fullest expression in the final pages of the book, he retained in convincing fashion the novel's strong pacifist appeal. He took substantial personal and financial risks, using a medium he wrote for but had never actively employed himself up to this point. His film should be regarded as a responsible artist's response to a highly problematic war, bearing a message that is universal, transcending the immediate context of American military involvement in Vietnam.

\section{References}

Cook, Bruce (1977) Dalton Trumbo. New York: Charles Scribner's Sons.

Greenspun, Roger (1971) “Johnny Got His Gun (1971) Pacifist Strategy of 'Johnny Got His Gun'”. New York Times, 5 August 1971. http://movies.nytimes.com (accessed on 24 March, 2012).

Hanson, Peter (2001) Dalton Trumbo, Hollywood Rebel; A Critical Survey and Filmography. Jefferson, North Carolina: McFarland and Company, Inc. Publishers.

Hopwood, Jon. C. "Biography for Dalton Trumbo". http://www.IMDB.com (accessed on 24 March, 2012).

Johnny Got His Gun (1971) Dir.: Dalton Trumbo, script: Dalton Trumbo, World Entertainment, DVD.

Nesbit, John. (n.d.) “Johnny Got His Gun: Oldschool Reviews by John Nesbit," http://oldschoolreviews.com, (accessed on 24 March, 2012).

Stam, Robert and Raengo Alessandra (eds.) (2005) Literature and Film, A Guide to the Theory and Practice of Film Adaptation. Maiden, MA, USA: Blackwell Publishing.

Trumbo, Dalton $(1939,1959)$ Johnny Got His Gun. A Bantam Book. http://ebookbrowse.com/ johnny-got-his-gun-pdf-d121193302, (accessed on 16 November, 2011).

Trumbo, Nikola (2005) “A Different Childhood.” Cinema Journal 44 (4), 96-100.

Wikipedia. "Metallica-One" http://en.wikipedia.org (accessed on 24 March, 2012).

TomÁš Pospí̌̌ll is Associate Professor at the Department of English and American Studies, Masaryk University Brno. He teaches American literature, American and Canadian film, and American cultural studies. He was an ACLS visiting scholar at the University of California, Santa Cruz in 1993/94, and Fulbright fellow at the USC, Los Angeles in 1999. More recently he has been visiting Canadian universities (University of Toronto, University of British Columbia) on a variety of shortterm fellowships. He is the author of The Progressive Era in American Historical Fiction: John Dos Passos' The 42 $2^{\text {nd }}$ Parallel and E.L. Doctorow's Ragtime (1998), Prüvodce cestovatele Amerikou (A Traveler's Guide through the Culture of the United States, 2001) and Sambo tu již nebydli? 
Obraz Afroameričanů v americkém filmu 20. století (Sambo Does Not Live Here Anymore? The African American Representation in American Film of the $20^{\text {th }}$ Century, 2003) He also co-authored the volume Us-Them-Me, the Search for Identity in Canadian Literature and Film (2009), where he contributed a chapter on Canadian feature film. His research interests involve African American film representation and North American feature film.

Address: doc. PhDr. Tomáš Pospíšil, Ph.D., Department of English and American Studies, Faculty of Arts, Masaryk University, Arna Nováka 1, 60200 Brno, Czech Republic. [tomas.pospisil@phil. muni.cz] 
